\title{
Zoledronik asit uygulamasının meme kanseri hücre hattı (MCF 7) kanser kök hücrelerinin üzerine otofaji gen seviyesindeki etkilerinin araştırılması
}

Investigation of the effects of zoledronic acid in breast cancer stem cell line (MCF 7) for autophagic gene level

\author{
Fatih Oltulu ${ }^{1}$ \\ Kubilay Doğan Kılıç ${ }^{1}$ \\ Ayşegül Uysal $^{1}$ \\ Hadi Rouhrazi ${ }^{2}$ \\ Duygu Çalık Kocatürk ${ }^{1}$ \\ Gülperi Öktem ${ }^{1}$ \\ ${ }^{1}$ Ege Üniversitesi Tıp Fakültesi, Histoloji ve Embriyoloji Anabilim Dalı, İzmir, Türkiye \\ ${ }^{2}$ Ege Üniversitesi Sağlık Bilimleri Enstitüsü, Tıbbi Biyokimya Anabilim Dalı, İzmir, Türkiye
}

\section{Öz}

Amaç: Zoledronik asit (ZA) uygulanmış meme kanser kök hücrelerinde $(\mathrm{KKH})$, kanser kök hücresi ve otofaji ile ilişkili gen ekspresyonlarındaki farklılıkları incelemek.

Gereç ve Yöntem: CD44 $4^{\text {yüksek} / C D 24} 4^{\text {yüksek }}$ yüzey belirteçleri pozitif olan MCF-7 meme kanseri hücre hattından KKH'ler akış sitometri metodu ile izole edilmiştir. ZA tedavisi uygulanmış ve uygulanmamış olan KKH gruplarının toplam RNA izolasyonu için cDNA sentezlenmiştir. Son olarak 41 adet otofaji için başlıca ilişkili olabilecek genlerin ekspresyon seviyeleri qRT-PCR analizi ile incelenmiştir.

Bulgular: ZA tedavisi uygulanan grup tedavi uygulanmayan grup ile karşılaştırıldığında TGM2, TNF, HSPA8 genlerinin azalmış regüle olduğu ve HSP90AA1 geninin artmış regüle olduğu görülmüştür.

Sonuç: Otofaji ile ilişkili genlerin ekspresyon profillerinde ZA tedavisi uygulanan ve uygulanmayan gruplar arasında anlamlı farklar bulunmuştur. Bu bulgular, KKH'lerine karşı hedef olabilecek daha etkili tedavi ajanları geliştirilebilmesi için önemli katkılar sağlayabilir.

Anahtar Sözcükler: Otofaji, kanser kök hücresi, zoledronik asit, tümör nekrozis faktör, ısı şok proteini (HSP 90).

\section{Abstract}

Aim: In this study we examined differences in the expression of genes associated with autophagy and CSCs for the treatment $Z A$ applied via taking breast cancer stem cells as models.

Materials and Methods: CSCs with $C D 44^{\text {high }} / C D 24^{\text {high }}$ surface markers have been isolated from the MCF-7 breast cancer cell line with flow cytometry methods. CDNA was synthesized for ZA treatment applied and not applied CSC group with total RNA isolation. Then, 41 essential autophagy-related gene expression levels were analyzed by qRT$P C R$ array analysis.

Results: When ZA treatment administrated group compared with non-treatment group, downregulation of TGM2, TNF, HSPA8 and upregulation of HSP90AA1 was detected.

Conclusion: There are differences of expression profiles of genes related to autophagy between $Z A$ treated and non-ZA tread group. These findings may provide important information towards us to target CSCs to develop more effective treatments.

Keywords: Autophagy, cancer stem cell, zoleodronic acid, TNF, heat shock protein (HSP90).

\footnotetext{
Yazışma Adresi: Fatih Oltulu

Ege Üniversitesi Tıp Fakültesi, Histoloji ve Embriyoloji Anabilim

Dalı, İzmir, Türkiye

E-posta: foltulugs08@hotmail.com

Makalenin Geliş Tarihi: 26.01.2018 Kabul Tarihi: 07.03.2018
} 


\section{Giriş}

Meme kanseri dünya çapında önemli bir sağlık yükü oluşturmaktadır. Kadınlar arasında, 2012'de küresel düzeyde 1.7 milyon yeni tanı ile en sık görülen kanserdir. Tüm kanserlerin \%25'ini oluşturup dünyada en sık görülen ikinci kanser tipidir. Birçok ülkede kadınların ana ölüm sebebidir. Düşük gelirli ülkelerde bu kanserden ölümler daha sıktır (1). Meme kanserinde mortalite genellikle primer tümör kaynaklı gerçekleşmezken; bunun yerine sıklıkla uzak organlara olan metastazlar nedeniyle gerçekleşmektedir (2). Mortalite, hastaların yaklaşı \% 50 'sinde kemik metastazı ile koreledir ve bu nedenle bu hastalarda kemik bütünlüğünü koruyabilmek oldukça önemlidir (3). Zoledronik Asit (ZA), prostat, akciğer ve kolorektal kanserler gibi bazı solid tümörlerin tedavisinde kullanılan bir üçüncü jenerasyon bifosfonattır (BP) (4). ZA, iskelet sistemi komplikasyonlarını azaltmak amacıyla osteolitik lezyonları bulunan meme kanserli hastalarda kullanılmaktadır. BP'lar, Ras, Rho ve Rac gibi küçük GTPaz'ların lipid frenilasyonlarını engelleyerek ve sonuç olarak ilişkili olduğu sinyal yolaklarını bloke edip osteoklast ve tümör hücrelerinin apoptozunu indükleyerek, aktivitesi mevalonat yolağı için kritik olan farnesil bisphosfanat (FPP) sentezini inhibe etmektedirler (5,6). ZA'nın in vitro anti-kanser aktivitesi, migrasyon, invazyon, adezyon ve proliferasyon azalması ve kanser hücrelerinin apoptozunun artması ile koreledir $(7,8)$. ZA'nın insan prostat kanseri hücrelerinde otofajik hücre ölümünü aktiflediği gösterilmiştir (9). ZA'nın indüklediği apoptoz ve inhibe ettiği koloni oluşumuna artmış otofaji eşlik etmektedir (10).

Tümör dokusu değişik hücre tiplerini içeren kompleks ve heterojen hücre popülasyonlarında oluşmaktadır. Son yıllarda yapılan çalışmalarda, bu heterojenik hücre popülasyonları arasında kanser kök hücresi $(\mathrm{KKH})$ adı verilen bir grup hücre tanımlanmıştır. Bu hücreler, tümör dokusu içinde varlıklarını sürdüren ve normal kök hücrelerin özelliklerine sahip olan hücrelerdir. KKH'leri kendi kendilerini yenileme ve farklı tümör alt gruplarına kaynak olabilme özellikleri ile tümör kitlesinin genelini oluşturan daha az tümörijenik kanser hücrelerinden (kanser kök hücresi olmayan kanser hücresi/ non-KKH) ayrılan küçük bir hücre popülasyonudur (11). KKH'lerini izole edip bu hücrelerin özelliklerini ve karakteristiklerini tanımlayabilmek, kanser tanı ve tedavisini anlamaya yönelen çalışmalar için anahtar rol oynamaktadır.

KKH'lerinin, kendini yenileme ve/ veya farklılaşma gibi fonksiyonel özellikleri ve kullandıkları sinyal yolakları normal kök hücreler ile benzerdir. Normal kök hücreler ve KKH'leri arasındaki temel fark bu ortak sinyal yolaklarının KKH'deki düzenlenmesinde ortaya çıkan değişikliklerdir $(11,12)$. Bu kendini yenileme ve farklılaşma özelliği bulunan KKH'leri sadece yeni tümör oluşumundan sorumlu olmayıp rekürrensler ve kemoterapi direncinden de muhtemel olarak sorumlu hücrelerdir (13). Yapılan son çalışmalar bu hipotezi destekler ve KKH'lerinin farklılaşmasını indüklemede birçok faktör olduğunu ortaya koymaktadır (14).

Hücre ölümünün düzenlenmesi, embriyonik gelişim ve doku homeostazisinde önemli bir ilk basamaktır. Bununla beraber, apoptotik mekanizmaların tetiklenmesi ve patolojik olayların tespit edilmesi hem hastalıkların yönetilmesinde hem de ilaç direncinde rol oynamaktadır. Son yıllarda hücrede ve dokuda hücre ölümünü kontrol eden birçok yolak tanımlanmıştır. Buna rağmen, embriyonik gelişim, homeostazis ve doku reorganizasyonunun kanser gibi patolojik koşullara katkıda bulunmasında etkili ve özellikle kontrol mekanizmalarında yer alan moleküller halen yapılan çalışmaların önemli miktarını oluşturmaktadır. Hücre ölümü sırasında oluşan morfolojik değişikliklerin apoptozis veya programlı hücre ölümü tip II olarak tanımlanan otofaji kaynaklı olduğunu anlamak zor olabilmektedir. Otofaji, membran biyogenezi, membran yeniden şekillenmesi ve veziküler trafiğinde içinde yer aldığı, birçok hastalıkla önemli rol oynayan katabolik bir süreçtir (15). Otofaji sırasında moleküler kontrol mekanizmaları apoptotik sinyal yolaklarını tetikleyerek hücre ölümüne neden olabilirler ancak bu süreci kontrol eden mekanizmaları ayırt etmek her zaman mümkün olamamaktadır (16).

Son çalışmalar otofajinin normal embriyonik gelişim ve doku kök hücrelerinin düzenlenmesindeki birçok fonksiyonunun yanı sıra KKH'lerinin kökeni, devamı ve sistemik dağılımında da önemli roller aldığına işaret etmektedir. Otofajinin, birçok KKH'nin yanı sıra embriyonik kök hücrelerin $(E K H)$, hematopoietik doku başta olmak üzere çoğu doku kök hücresinin düzenlenmesinde yerini gösteren birçok veri toplanmaktadır (17).

Çalışmamızda ZA'nın meme kanseri hücre hattından (MCF 7) izole edilen KKH'lerine etkisinin incelenmesi amaçlanmıştır. Meme KKH'lerinin apoptoz/otofaji süreçlerine ZA'nın etkileri gen seviyesinde yapılan deneyler ile gösterilmiştir. Bu çalışmada, KKH'lerinde apoptoz/otofaji süreçlerini oluşturabilecek faktörleri ve oluşum mekanizmalarını daha iyi anlamak hedeflenmektedir. Bu şekilde, pahalı, birçok yan etkisi olan kemoterapi ve radyoterapi gibi uzun süreli tedavilere dirence, nüksler ve metastazlara sebep olduğu düşünülen KKH'lerinin hücre ölüm mekanizmalarını daha iyi anlayabilmenin gelecek tedaviye yönelik çalışmalar için öncü olabileceğine inanılmaktadır.

\section{Gereç ve Yöntem}

Hücre kültürü

İnsan meme kanseri hücre hattı MCF7, American Type Culture Collection'dan (Manasas, VA, USA) temin 
edilmiştir. Hücreler, \%10 fetal bovin serumu (FBS) (Gibco, Invitrogen Life Technologies, Paisley, UK), \%1 penisilin ve streptomisin (Sigma-Aldrich, St Louis, MO, USA) içeren RPMI 1640 (Lonza, Basel, Switzerland) kültür besiyerinde, $37^{\circ} \mathrm{C}$ nemli atmosfere sahip $\% 5 \mathrm{CO}_{2}$ varlığındaki inkübatör içinde büyütülmüştür. Hücreler yaklaşık flask içinde $\% 80$ yoğunluğa ulaşıldığında $\% 0.05$ tripsin (Sigma-Aldrich) ve tripsini inaktive etmek için RPMI 1640 kullanılarak, 5dk 1000 rpm'de Eppendorf Centrifuge 5804R ile santrifüje edilerek standart pasaj protokolleri ile pasajlanmıştır. Santrifüj sonrası hücreler tekrar kültür besiyeri ile süspansiyon haline getirilmiştir ve hücre kültürü flasklarına konularak aynı inkübatör koşullarında büyütülmeye devam edilmiştir.

Floresan aktive hücre seçimi (FACS)

Toplamadan önce flask içinde hücre yoğunluğunun \%80'e ulaşması beklenmiştir. Hücre seçimi için hücreler enzimatik olmayan hücre ayırma solüsyonu (SigmaAldrich) kullanılarak yüzeyden ayrılmış ve santrifüj sonrasında Dulbecco's phosphate-buffered saline (DPBS, Invitrogen, USA)'de resüspanse edilmişlerdir. Yaklaşık olarak $5 \times 10^{4}$ hücre akış sitometrisinde seçim için kullanılacak olan CD44 ve CD24 antikorları ile (1:100 in FACS yıkama ile $0.5 \%$ bovine serum albumin; $2 \mathrm{mM} \mathrm{NaN}_{3}$ and $5 \mathrm{mM}$ EDTA) 15 dakika, $4^{\circ} \mathrm{C}$ 'de inkübe edilmiştir. MCF 7 hücreleri için, PE-etiketli CD24 ve FITC-etiketli CD44 monoklonal antikorları kullanılmıştır. İnübasyon sonrasında hücreler santrifüje edilmiş ve yıkanarak tekrar süspanse edilmişlerdir. Hücreler, FACS (FACSAria; BD Biosciences, San Jose, CA, USA) makinesi kullanılarak CD44 $4^{\text {yüksek} / C D 24} 4^{\text {yüksek }}$ popülasyonda olacak şekilde seçilmişlerdir (18) ve sonucunda yüzey belirteci pozitif olan hücre grubu ve negatif olan hücre grubu olarak ayrılmışlardır. Bu grupların saflıkları ayırma sonrası FACS Aria flow sitometrisi analizi ile değerlendirilmiş ve \%85 ve üzerindeki saflığa sahip örnekler deneylerde kullanılmıştır.

\section{ZA uygulanması}

Hücreler, düz zeminli 6 kuyucuklu hücre kültürü plakalarına, her bir kuyucukta $1 \times 10^{5}$ yoğunluğunda hücre olacak şekilde kültür besi yeri içinde plakaya yapışması için inkübatörde gece boyunca bırakılmıştır. Sonrasında hücrelere $100 \mu \mathrm{M}$ konsantrasyonunda ZA uygulanmış ve hücreler 72 saat boyunca $37^{\circ} \mathrm{C}$ nemli atmosfere sahip $5 \% \mathrm{CO}_{2}$ varlığındaki inkübatörde inkübe edilmişlerdir. Kontrol grubu hücreleri, aynı inkübatör şartlarında ve aynı hücre yoğunluğunda 6 kuyucuklu plakalara ekilerek sadece hücre kültürü besi yeri uygulanarak aynı sürede inkübatörde büyütülmüşlerdir.

Polimeraz zincir reaksiyonu (PCR) sekanslama

Yüzey belirteci pozitif veya negatif olarak ayrılmış hücrelerin toplam RNA'sı 'miRNeasy' (Kit Qiagen, Germany) kullanılarak ayrılmıştır ve cDNA sentezi
'SuperArray Kit' (SA Biosciences, CA, C-03) kullanılarak gerçekleştirilmiştir. Kök hücre spesifik gen ekspresyon profili Roche Custom Panel 384 ile üreticinin talimatları izlenerek PCR sekanslama metodu ile gerçekleştirilmiştir. Toplam RNA, tüm serbest sferoitlerden veya tek katmanlı hücre popülasyonlarından izole edilmiştir. Toplam RNA $1 \mu \mathrm{g}$ DNaz ile muamele edilmiş ve cDNA 'RT2 First Strand Kit' ile hazırlanmıştır. cDNA kontrol ve test çiftleri 'RT2 qPCR Master Mix' solüsyonu ile karıştırılarak 41 adet kök hücre ilişkili gen ve her analiz için kontrol housekeeping genlerinin probunu içeren 96 kuyucuklu PCR sekanslama plakalarına gönderilmiştir. Amplifikasyon işlemi verileri (her genin Ct değerinin değişimi), LightCycler 480 (LC 480, Roche Molecular Systems) kullanılarak gerçekleştirilen gerçek zamanlı PCR sonrasında elde edilmiş ve sistem yazılımı ile analiz edilmiştir. Seçilim kriteri olarak iki kat ve üzeri değişimler kabul edilmiştir.

\section{İstatistiksel analiz}

Tüm deneyler 3 kez tekrarlanarak yürütülmüştür. İstatistiksel analiz, tek yönlü varyans analizi ve ardından Tukey's veya Dunett's post hoc testi kullanılarak yapılmıştır. $p<0.05$ istatistiksel anlamlı fark olarak kabul edilmiştir.

\section{Bulgular}

CD44 ${ }^{\text {yüksek} / C D 24} 4^{\text {yüksek }}$ Yüzey belirteçleri ile seçilmiş/ seçilmemiş hücre alt gruplarının saflık ve ayrım analizi

MCF 7 insan meme kanseri hücre hattı hücreleri CD44 ve CD24 yüzey belirteçleri ile FACS yöntemi ile ayrılmışlardır. MCF $7 \mathrm{KKH}$ ve non-KKH'si oranlarının seçilmiş hücreler için $3.9 \pm 5.4$ ve seçilmemiş hücreler

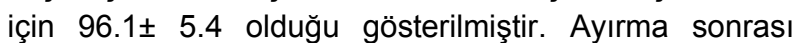
analizi ile seçilmiş hücrelerin saflığının \%85 ve üzerinde olduğu belirlenmiştir.

\section{$R T-P C R$ analizi}

MCF 7 KKH'lerinin ZA uygulanmış veya kontrol gruplarının karşılaştırılmalı incelenen 41 geninde ekspresyon değişimleri tespit edilmiştir (Şekil 1). Gen ekspresyonlarının fold change değerleri Tablo-1'de gösterilmiştir. HSP90AA1 (1. Var.), HSPA8 (2. Var.), TGM2 ve TNF genleri için ZA uygulanmış veya kontrol gruplarının karşılaştırılmasında anlamlı değişim gözlemlenmiştir. ZA tedavisi uygulanan grup uygulanmayan ile karşılaştırıldığında, TGM2, TNF ve HSPA8 genleri azalmış regüle olurken HSP90AA1 geninin artmış regüle olduğu görülmüştür.

Özellikle vurgulamak gerekirse TNF ile ilişkili olan NFkB, tüm vücut hücrelerinde ifade edilen AKT 1 ve apoptoz ile ilişkili olan BAX, Bcl- 2 ve Caspaz 3 düzeylerinde guruplar arasında anlamlı fark saptanmamıştır. 


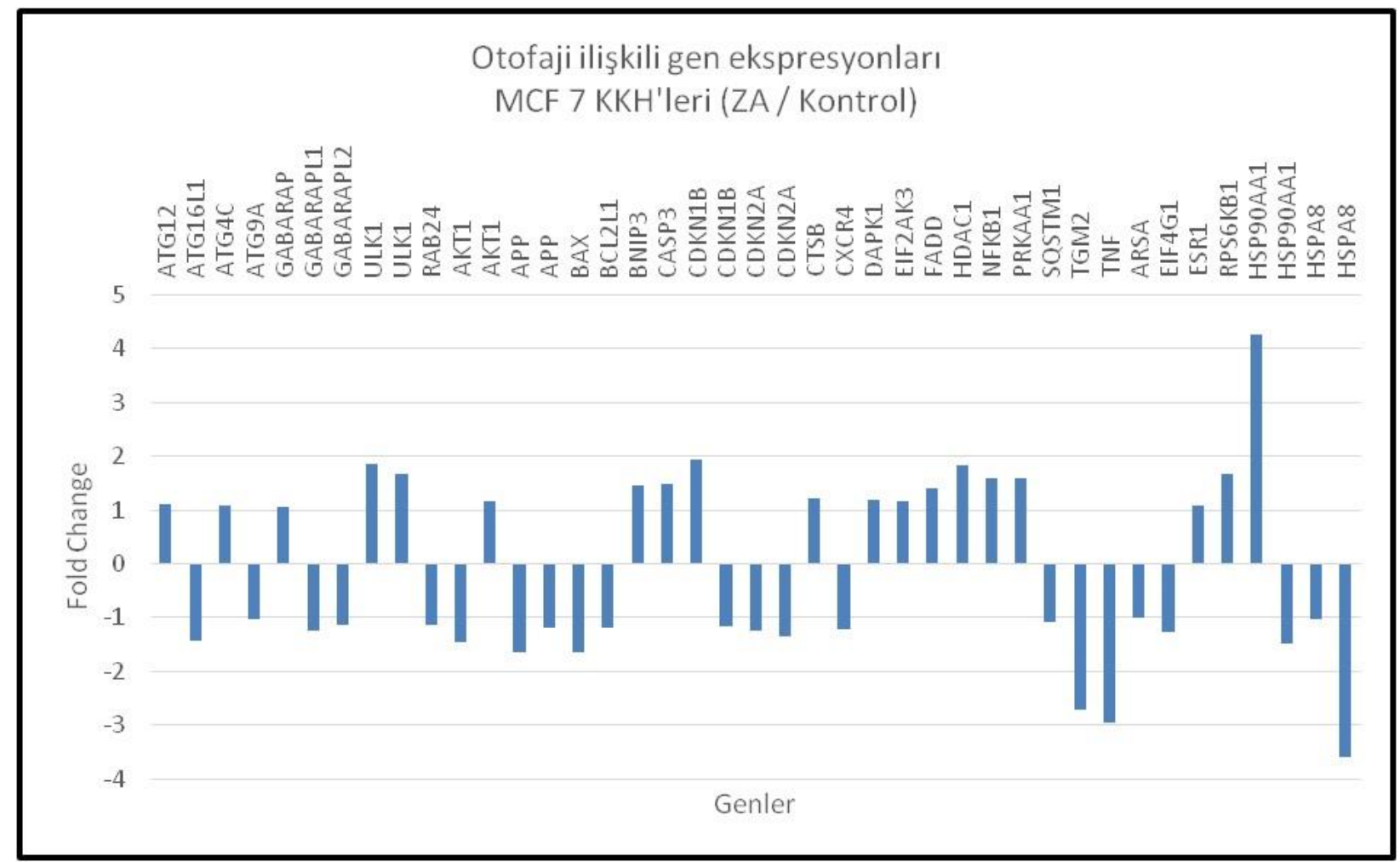

Şekil-1. MCF 7 KKH'lerindeki ZA uygulanan ve uygulanmayan grupların otofaji ilişkili gen ekspresyonlarındaki anlamlı değişimlerin gösterimi.

Tablo-1. Otofaji Illişkili Genlerin Ekspresyonlarının MCF 7 KKH'lerinin ZA Uygulanmış/Kontrol Gruplarındaki Fold Change Değerleri.

\begin{tabular}{|c|c|c|c|}
\hline Gene Symbol & $\begin{array}{l}\text { Fold Change } \\
\text { MCF7 CSCS (ZA / Control) }\end{array}$ & Gene Symbol & $\begin{array}{l}\text { Fold Change } \\
\text { MCF> CSCS (ZA / Control) }\end{array}$ \\
\hline ATG12 & 1.1007503 & CDKN2A (2. Var.) & -1.359953 \\
\hline ATG16L1 & -1.43387 & CTSB & 1.2074106 \\
\hline ATG $4 \mathrm{C}$ & 1.0687882 & CXCR4 & -1.2110881 \\
\hline ATG9A & -1.0362397 & DAPK1 & 1.193906 \\
\hline GABARAP & 1.0436645 & EIF2AK3 & 1.1665611 \\
\hline GABARAPL1 & -1.2335453 & FADD & 1.399989 \\
\hline GABARAPL2 & -1.1388941 & HDAC1 & 1.81604 \\
\hline ULK1 (1. Var.) & 1.8555173 & NFKB1 & 1.5805583 \\
\hline ULK1 (2. Var.) & 1.6734324 & PRKAA1 & 1.5892819 \\
\hline RAB24 & -1.1291269 & SOSTM1 & -1.0884393 \\
\hline AKT1 (1. Var) & -1.4559768 & TGM2 & -2.701134 \\
\hline AKT1 (2. Var) & 1.1669518 & TNF & -2.9504821 \\
\hline APP (1. Var.) & -1.6366683 & ARSA & -1.0007664 \\
\hline APP (2. Var.) & -1.1920114 & EIF4G1 & -1.2615596 \\
\hline BAX & -1.6356333 & ESR1 & 1.0847439 \\
\hline BCL2L1 & -1.1837041 & RPS6KB1 & 1.6679822 \\
\hline BNIP3 (1. Var.) & 1.4452448 & HSP9OAA1 (1. Var.) & 4.2494845 \\
\hline CASP3 (2. Var.) & 1.4848363 & HSP9OAA1 (2. Var.) & -1.4902918 \\
\hline CDKN1B (1. Var.) & 1.9417897 & HSPA8 (1. Var.) & -1.0184727 \\
\hline CDKN1B & -1.1503958 & HSPA8 (2. Var.) & -3.5891192 \\
\hline CDKN2A (1. Var.) & -1.2313057 & & \\
\hline
\end{tabular}




\section{Tartışma}

Diğer doku kök hücreleri gibi KKH'leri de kendilerini yenileyebilen hücrelerdir. $\mathrm{Bu}$ hücreler ayrıca kemoterapötiklere ve radyoterapiye dirençlidirler ve bulundukları dokulardan farklı dokularda çoğalabilirler. Günümüzde, kanser tedavisinin zorluklarını KKH'lerin bu özelliklerine bağlamak yanlış değildir. Bu sebeplerle kanserin tedavisinde, KKH'lerini hedef almak doğru yaklaşım olacaktır. KKH'lerini özetlemek gerekirse; 1.Kendini yenileyebilme, 2.Farklılaşma, 3 Kemoradyoterapi ve otofaji / apoptoz gibi hücre ölüm çeşitlerine karşı dirençli olmak gibi 3 temel özelliğe sahiptirler (19). Otofaji, tüm hücrelerde var olan; protein sirkülasyonu ve organellerin düzenlenmesi ile homeostazı destekleyen temel bir mekanizmadır. Yeni çalışmalar, otofajinin, normal embriyonik ve doku kök hücrelerindeki birçok işlevinin yanı sıra KKH'lerinin kökeni, sürdürülmesi ve sistemik dağılımında da önemli bir rol oynadığını düşündürmektedir. KKH'lerinin biyofiziksel stresli çevre koşullarında toleransının artmasını, kök hücre özelliklerini sürdürürken kök hücre popülasyonunu arttırmasını, otofajinin nası sağlayabildiği maalesef az sayıda çalışma ile gösterilebilmiştir (17). Son zamanlarda yapılan birçok çalışmada, apoptoz ile otofaji yolağının moleküler seviyedeki karmaşık ilişkileri düzenlenebilir, aynı sinyal bağlantısı ile yönlendirilebilir ve bazı ortak proteinlerin bu iki sistemin her biriyle olan ilişkilerini düzenliyor olmaları muhtemeldir (20). KKH'leri ile otofaji / apoptoz arasındaki ilişki ağı tam olarak ortaya konmamıştır. Bizim çalışmamızda ZA uygulanmış ve uygulanmamış olan KKH'leri arasındaki farklılıkların otofajik mekanizmalar aracılığı ile olup olmadığı incelenmiştir. ZA tedavisi uygulanan grup uygulanmayan ile karşılaştırıldığında, TGM2, TNF ve HSPA8 genleri azalmış regüle olurken HSP90AA1 geninin artmış regüle olduğu gözlemlenmiştir.

Tümör nekroz faktörü (TNF) ile ilişkili apoptozu indükleyen ligand (TRAIL), TNF süper ailesine aittir ve ekstrinsik apoptoz yolunu aktive ederek apoptozu başlatabilmektedir (21). Normal hücrelere zarar vermeden kanser hücrelerinde apoptozu seçici olarak indükleyebilmektedir (22). Kanser hücrelerinde otofajinin hayatta kalma mekanizması olup olmadığı veya tip 2 programlı hücre ölümü ile ilişkili olup olmadığı halen belirsizdir (23). Özellikle immun sistem hücrelerinde, TNF reseptör ailesinden Fas'ın Fas liganda (FasL) bağlanması, ekstrinsik apoptotik yolağın aktiflenmesi için bir uyarıdır. Bu bağlanma, Fas'ın oligomerleşmesine yol açar ve Fas (reseptör), FADD (adaptör) ve kaspaz 8 ile ölüm kompleksi tarafından idameli kaspazların aktivasyonuyla sonuçlanır. Fas ayrıca RIP kinaz aracılığıyla kaspazlardan bağımsız olarak hücre ölümüne neden olabilmektedir. Fakat bu kaspaz bağımsız hücre ölümünün moleküler mekanizmaları net olarak bilinmemektedir. Çalışmalar, kaspaz 8'in RIP kinazı parçalayıp bu yolağı ortadan kaldırdığını göstermiştir (24). Kaspaz 8'in bloke edilerek otofajinin RIP kinaz ile uyarılması, oksidatif stres ve katalaz degredasyonu ilişkili hücre ölümüne neden olmaktadır (25). Bütün bu bulgular, otofaji / apoptoz arasındaki ilişkinin, hücre ölümü veya sağ kalımı kararını reseptörleri aracılığıyla hücre ölümünü aktifleyerek etkilediğini göstermektedir (20). Bizim çalışmamızda, ZA uygulanmamış grup ile karşılaştırıldığında gözlemlenmiş olan ZA uygulanmış gruptaki düşük TNF seviyeleri, literatürde sunulan bilgilerin aksine apotozis inhibitörleri (IAP) ailesi proteinleri ile ilişkilendirilmektedir.

Birçok çalışmada, IAP ailesinin ve TNF reseptör (TNFR) ailesinin proteinlerinin aynı sinyal iletim yolaklarını kullandıkları gösterilmiştir. TNFR ailesinin tüm üyelerinin hücre içi parçaları değişiklikler gösterebiliyor olmasına rağmen, hücre dışı kısımları benzer aminoasit sekansı paylaşmaktadır. TNFR1 ve TNFR2 bu ailenin önemli temsilcilerindendir (26). İnsan c-IAP1 ve c-IAP2 proteinleri TNFR2 reseptör kompleksiyle olan bağlantılarıyla keşfedilmiştir (27). C-IAP2, fonksiyonel olarak TNF'nin NFkB'yi indükleme yoluna dahildir ve apoptozisten korunmada rol oynamaktadır. Illk olarak, TNF'nin NFkB aracılığıla c-IPA2 ekspresyonunu indüklediği gösterilmiştir. Daha sonra, c-IAP2'nin artmış ekspresyonunun, TNFR1 aracılığıla TNF ile indüklenen hücre ölümünü baskıladığı gösterilmiştir. Sonuç olarak, cIAP2'nin TNF ile indüklenen apoptozu baskılamak için NFkB'nin rol aldığı sinyal yollarında kritik bir role sahip olduğunu söylenebilmektedir (28).

Transglutaminaz 2 (TGM2), GTP bağlanma aktivitesi, kalsiyum bağımlı protein çaprazlanması, protein disülfit izomeraz aktivitesi, serin/treonin kinaz aktivitesi ve inflamasyon gibi çok çeşitli reaksiyonları katalizleyen hem yapısal hem de enzimatik proteindir ve yara iyileşmesi ve kanser gibi önemli olaylarda anahtar rol oynamaktadır. Çalışmalar, epidermal KKH'lerinin, kanser kök hücresi olmayan tümör hücrelerine kıyasla oldukça yüksek miktarda TGM2 depoladığını göstermektedir. Çeşitli knockdown ve inhibitör çalışmaları ile, TGM2'nin sağ kalım, göç ve EKH'nin invazyonu için gerekli olduğu gösterilmiştir. TGM2'nin inhibisyonu EKH'lerde apoptozu aktive eder. TGM2'nin, aynı epidermal skuamöz kanser hücrelerinde arttığı gibi EKH'lerde de oldukça spesifik ve belirgin şekilde yükseldiği gösterildiğinde, buna bağlı olarak EKH sağ kalımında rol aldığı düşünülmektedir $(29,30)$. Bizim çalışmamızda, ZA uygulanmış olan KKH'si TGM2 ekspresyonunun kontrol gurubu TGM2 ekspresyonuna göre azaldığı gözlemlenmiştir. ZA tedavisi ile KKH'lerinde TGM2'nin azalmış olması ve bunun sonucunda muhtemel olarak indüklenmiş olabilecek apoptoz, TGM2'nin KKH'lerinin sağ kalımındaki kritik yerine işaret etmektedir. Gerçekleştirilebilecek olan 
tedaviye yönelik çalışmalarda, TGM2 hedef alınması terapötik ajan geliştirilmesinde pozitif sonuçlar alınabilineceğine işaret etmektedir.

Isı şok proteinleri (HSP) programlanmış hücre ölüm yollarının çeşitli yerlerinde etkilidirler. HSP70 ailesi, proliferasyon invazyon ve metastaz gibi tümörigenez fenotipleriyle ilişkilidir. $\mathrm{Bu}$ aile üyelerinin insan kanserlerindeki anti-apoptotik etkiyi artırdığı gösterilmiştir. HSPA8 de sürekli olarak eksprese olan bu aile üyesi bir moleküler şaperondur. HSPA8 geninin ekspresyonu, sodyum arsenit, organoklorin, nikel, kadmiyum, östrojen ve progesteron gibi faktörler tarafından düzenlenebilmektedir (31,32). HSPA8 geni, kanser hücrelerinin büyümesi için gereklidir ve bu hücrelerde aşırı ifade edilmektedir. Çalışmalarda, HSPA8 tükenmesi ile hücre proliferasyonunda önemli bir azalmanın olduğu açık deliller ile gösterilmiştir. HSPA8, siRNA transfeksiyonu yoluyla hem erken hem de geç apoptozu indüklemekle kalmaz, aynı zamanda $S$ fazı yüzdesini de arttırabilmektedir (33). Bizim çalışmamızda, ZA uygulanmış olan KKH'si HSPA8 ekspresyonunun kontrol gurubu HSPA8 ekspresyonuna göre azaldığı gözlemlenmiştir. Bu azalma ile, otofaji ve apoptoz gibi programlanmış hücre ölüm mekanizmalarında da anlamlı oranda azalma olabileceği düşünülmektedir.

İnsanlarda HSP90 birden çok izoforma sahiptir. HSP90a, hücresel stresle indüklenen iyi bilinen bir sitoplazmik izoformdur (34). İnsan $T$ hücresindeki HSP90AA1 ekspresyonu, IL-2, IL-4 IL-13 gibi sitokinler tarafından arttırılabilmektedir (35). Lösemide, HSP90a upregüledir ve hastalık prognozuyla korele olmaktadır (36). Artan Hsp90a düzeyleri meme ve pankreas kanserinde kötü prognozun bir göstergesidir (37). Hsp90a protein ekspresyonundaki değişikliğe rağmen, The Cancer Genome Atlas'a göre HSP90AA1 değişikliği çoğu kanser çeşidinde görülmemektedir (38). HSP90AA1 geninde homozigot delesyon oluştuğunda tümörlerde malignitenin azaldığı düşünülmektedir. Mide kanseri için karşılaştırmalı gen analizi çalışmalarında cerrahi sonrası HSP90AA1 kaybı olan hastalarda daha iyi sonuçlar gözlenmiştir (39). Tümör biyopsilerinde HSP90 $\alpha$ yokluğunun daha iyi klinik sonuçlar için bir biyobelirteç olduğunu gösterecek çalışmalar mevcuttur (40). Bizim çalışmamızda, ZA ile tedavi edilen $\mathrm{KKH}$ 'leri ve tedavi edilmemiş $\mathrm{KKH}$ 'si kontrol grubu HSP90AA1 gen ekspresyonları karşılaştırıldığında tedavi grubunda HSP90AA1 gen ekspresyonunda artış olduğu bulunmuştur.

HSP90 onkogenezi destekleyen birçok protein ile etkileşim halindedir (41). Hücre içi fonksiyonlarının yanı sıra, yara iyileşmesi ve inflamasyon gibi ekstravazasyon veya metastaz benzeri malign hücre davranışlarına yardımcı olan süreçlerde hücre dışı olarak da salınmaktadır (42). Son araştırmalar ile uyarıımış fibroblastlardan da salınabileceği öne sürülmektedir. Bu nedenle, mevcut tüm veriler ileri kanser hastalarının kan plazmasında yüksek HSP90 $\alpha$ seviyesini (43) ve ZA tedavi grubundaki HSP90AA1 geninin yüksek ekspresyonunu açıklayabilmektedir.

Analiz edilen genler, sadece otofajik vakuollerden, membran protein hedeflemesinden, protein taşınımından, ubikitinasyon ve proteaz aktivitesini içeren gen grupları ile ilişkili değil aynı zamanda şaperon aracılı otofaji genlerinin oluşumunda rol oynayan genler olarak da sınıflandırılabilmektedirler.

\section{Sonuç}

HSP90AA1'in KKH ve TNF ile ilişkisi henüz tam olarak ortaya konamamıştır. Çalışmamızın sonuçları, bu iki molekülün gelecek günlerde kanser tedavilerinin geliştirilmesinde etkili olabileceğini göstermektedir.

\section{Kaynaklar}

1. Ghoncheh M, Pournamdar Z, Salehiniya H. Incidence and Mortality and Epidemiology of Breast Cancer in the World. Asian Pac J Cancer Prev. 2016;17:43-6.

2. Weigelt B, Peterse JL, van't Veer LJ. Breast cancer metastasis: markers and models. Nat Rev Cancer. 2005;5(8):591-602.

3. Aft R. Protection of bone in premenopausal women with breast cancer: focus on zoledronic acid. Int $\mathrm{J}$ Womens Heal. 2012;4:569-76.

4. Barrett-Lee $\mathrm{P}$, Casbard $\mathrm{A}$, Abraham J, et al. Oral ibandronic acid versus intravenous zoledronic acid in treatment of bone metastases from breast cancer: A randomised, open label, non-inferiority phase 3 trial. Lancet Oncol. 2014;15(1):114-22.

5. Coxon FP, Rogers MJ. The role of prenylated small GTP-binding proteins in the regulation of osteoclast function. Calcif Tissue Int. 2003;72(1):80-4.

6. Body JJ, Bartl R, Burckhardt P, et al. Current use of bisphosphonates in oncology. Vol. 16, Journal of Clinical Oncology. 1998. p. 3890-9.

7. Dedes PG, Gialeli C, Tsonis Al, et al. Expression of matrix macromolecules and functional properties of breast cancer cells are modulated by the bisphosphonate zoledronic acid. Biochim Biophys Acta. 2012;1820(12):1926-39.

8. Mani J, Vallo S, Barth K, et al. Zoledronic acid influences growth, migration and invasive activity of prostate cancer cells in vitro. Prostate Cancer Prostatic Dis. 2012;

9. Lin J-F, Lin Y-C, Lin Y-H, et al. Zoledronic Acid Induces Autophagic Cell Death in Human Prostate Cancer Cells. J Urol. 2011;185(4):1490-6.

Cilt 58 Sayı 1, Mart 2019 / Volume 58 Issue 1, March 2019 
10. Ge XY, Yang LQ, Jiang Y, Yang WW, Fu J, Li SN. Reactive oxygen species and autophagy associated apoptosis and limitation of clonogenic survival induced by zoledronic acid in salivary adenoid cystic carcinoma cell line SACC-83. PLoS One. 2014;9(6).

11. Yu Z, Pestell TG, Lisanti MP, Pestell RG. Cancer stem cells. Int J Biochem Cell Biol. 2012;44(12):2144-51.

12. Singh SK, Clarke ID, Terasaki $M$, et al. Identification of a cancer stem cell in human brain tumors. Cancer Res. 2003;63(18):5821-8.

13. La Porta CA. Mechanism of drug sensitivity and resistance in melanoma. Curr Cancer Drug Targets. 2009;9(3):391-7.

14. Yin G, Alvero a B, Craveiro V, et al. Constitutive proteasomal degradation of TWIST-1 in epithelial-ovarian cancer stem cells impacts differentiation and metastatic potential. Oncogene. 2013;32(1):39-49.

15. Levine B, Yuan J. Autophagy in cell death: An innocent convict? Vol. 115, Journal of Clinical Investigation. 2005. p. 2679-88.

16. Betin VMS, Lane JD. Caspase cleavage of Atg4D stimulates GABARAP-L1 processing and triggers mitochondrial targeting and apoptosis. J Cell Sci [Internet]. 2009;122(14):2554-66. Available from: http://jcs.biologists.org/cgi/doi/10.1242/jcs.046250

17. Guan JL, Simon AK, Prescott M, et al. Autophagy in stem cells. Autophagy. 2013;9(6):830-49.

18. Jaggupilli A, Elkord E. Significance of CD44 and CD24 as cancer stem cell markers: An enduring ambiguity. Vol. 2012, Clinical and Developmental Immunology. 2012.

19. Ural AU. Cancer Stem Cells: Current Concepts and Therapeutic Implications. In: Turksen K, editor. Adult and Embryonic Stem Cells. Totowa, NJ: Humana Press; 2012. p. 227-35.

20. Arslan DÖ, Korkmaz G, Gözüaçık D. Otofaji: Bir Hücresel Stres Yanıtı ve Ölüm Mekanizması. 2011;

21. Wiley SR, Schooley K, Smolak PJ, et al. Identification and characterization of a new member of the TNF family that induces apoptosis. Immunity. 1995;3(6):673-82.

22. Ashkenazi A, Pai RC, Fong S, et al. Safety and antitumor activity of recombinant soluble Apo2 ligand. J Clin Invest. 1999;104(2):155-62.

23. Kelekar A. Introduction to the review series Autophagy in Higher Eukaryotes--a matter of survival or death. Autophagy. 2008;4(5):555-6.

24. Yu L. Regulation of an ATG7-beclin 1 Program of Autophagic Cell Death by Caspase-8. Science (80- ). 2004;304(5676):1500-2.

25. Yu L, Wan F, Dutta S, et al. Autophagic programmed cell death by selective catalase degradation. Proc Natl Acad Sci. 2006;103(13):4952-7.

26. Singh A, Ni J, Aggarwal BB. Death domain receptors and their role in cell demise. J Interferon Cytokine Res. 1998;18(7):439_ 50.

27. Rothe M, Pan MG, Henzel WJ, Ayres TM, Goeddel D V. The TNFR2-TRAF signaling complex contains two novel proteins related to baculoviral inhibitor of apoptosis proteins. Cell. 1995;83(7):1243-52.

28. Chu Z-L, McKinsey TA, Liu L, Gentry JJ, Malim MH, Ballard DW. Suppression of tumor necrosis factor-induced cell death by inhibitor of apoptosis C-IAP2 is under NF-KB control. Proc Natl Acad Sci. 1997;94(19):10057-62.

29. Fisher ML, Keillor JW, Xu W, Eckert RL, Kerr C. Transglutaminase Is Required for Epidermal Squamous Cell Carcinoma Stem Cell Survival. Mol Cancer Res. 2015;13(7):1083-94.

30. Pastor MD, Nogal A, Molina-Pinelo S, Carnero A, Paz-Ares L. Proteomic biomarkers in lung cancer. Clin Transl Oncol. 2013;15(9):671-82.

31. Murphy ME. The HSP70 family and cancer. Carcinogenesis. 2013;34(6):1181-8.

32. Maehara $\mathrm{Y}$, Oki E, Abe T, et al. Overexpression of the heat shock protein HSP70 family and p53 protein and prognosis for patients with gastric cancer. Oncology. 2000;58(2):144-51.

33. Shan N, Zhou W, Zhang S, Zhang Y. Identification of HSPA8 as a candidate biomarker for endometrial carcinoma by using iTRAQ-based proteomic analysis. Onco Targets Ther. 2016;9:2169.

34. Ammirante M, Rosati A, Gentilella A, et al. The activity of hsp90 alpha promoter is regulated by NF-kappa B transcription factors. Oncogene. 2008;27(8):1175-8.

35. Metz K, Ezernieks J, Sebald W, Duschl A. Interleukin-4 upregulates the heat shock protein Hsp90a and enhances transcription of a reporter gene coupled to a single heat shock element. FEBS Lett. 1996;385(1-2):25-8.

36. Yufu Y, Nishimura J, Nawata H. High constitutive expression of heat shock protein 90 alpha in human acute leukemia cells. Leuk Res. 1992;16(6-7):597-605.

37. Jameel A, Skilton RA, Campbell TA, Chander SK, Coombes RC, Luqmani YA. Clinical and biological significance of HSP89 alpha in human breast cancer. Int $J$ Cancer [Internet]. 1992;50(3):409-15. Available from: http://www.ncbi.nlm.nih.gov/pubmed/1735610

38. Gao J, Aksoy BA, Dogrusoz U, et al. Integrative Analysis of Complex Cancer Genomics and Clinical Profiles Using the cBioPortal. Sci Signal. 2013;6(269):pl1-pl1.

39. Buffart TE, Carvalho B, van Grieken NCT, et al. Losses of chromosome $5 q$ and $14 q$ are associated with favorable clinical outcome of patients with gastric cancer. Oncologist. 2012;17(5):653-62.

40. Gallegos Ruiz MI, Floor K, Roepman P, et al. Integration of gene dosage and gene expression in non-small cell lung cancer, identification of HSP90 as potential target. PLoS One. 2008;3(3):e0001722.

41. Workman P, Burrows F, Neckers L, Rosen N. Drugging the cancer chaperone HSP90: Combinatorial therapeutic exploitation of oncogene addiction and tumor stress. In: Annals of the New York Academy of Sciences. 2007. p. 202-16.

42. Eustace BK, Sakurai T, Stewart JK, et al. Functional proteomic screens reveal an essential extracellular role for hsp90a in cancer cell invasiveness. Nat Cell Biol. 2004;6(6):507-14.

43. Wang $X$, Song $X$, Zhuo $W$, et al. The regulatory mechanism of Hsp90a secretion and its function in tumor malignancy. Proc Natl Acad Sci. 2009;106(50):21288-93. 